\title{
15. Some aspects of the transmission mechanism
}

A common allegation is that monetary economics lacks a theoretically integrated and empirically plausible account of 'the transmission mechanism', where the transmission mechanism is the process (or set of processes) by which changes in the quantity of money lead to changes in national income. ${ }^{1}$ As monetarism would be incomplete without a transmission mechanism, this allegation would be serious if it were true. In fact, monetary economics has a simple and persuasive body of ideas which relates the quantity of money to asset prices and national income, and which has been passed down through successive generations of teachers and students at some universities, although certainly not all. (In one case the ideas formed the celebrated 'oral tradition' of Chicago monetary economics. ${ }^{2}$ ) However, monetary economics is no longer taught with much rigour in most British universities and the transmission mechanism from money to the economy is undoubtedly a mystery to many British economists.

I set up a company, Lombard Street Research, in July 1989. My main aim in establishing the company was to maintain an approach to macroeconomic analysis which I had developed in the 1970s and 1980s as a journalist on The Times, and, in much more detail, as an economist at the stockbrokers, L. Messel \& Co., and the investment bank, Shearson Lehman (now Lehman Brothers). My ambition was that Lombard Street Research would prove a viable home for a continuing UK macroeconomic forecast with a large role for money. The model contained a transmission mechanism - or rather a number of transmission mechanisms - in which money influenced expenditure on goods and services, both directly and indirectly via asset markets and prices. The purpose of this paper is to outline the development of my thinking on macroeconomic policy, to describe some of the key ideas in the Lombard Street Research approach and to see how well they survived the 15 years to 2004. (I left Lombard Street Research in September 2005.) 
The two core principles of the approach were not original. They were - and still are - to be found, in one form or another, in virtually every macroeconomics textbook. They are that,

- national income is in equilibrium only when the demand for money is equal to the supply of money (that is, when monetary equilibrium prevails), and,

- the demand to hold money balances (that is, the demand for money) is a stable function of a small number of variables, notably income and the attractiveness of money relative to the nearest alternative asset.

The first principle is integral to a large number of economic models. For example, it is contained in the IS-LM model of national income determination which was devised by Hicks in 1937 as a way of reconciling Keynes's General Theory with 'the classics'. The second principle is sometimes deemed to have an ideological tinge, since much of the most influential work in estimating demand-for-money functions was carried out by Professor Milton Friedman, a champion of free market economics. But demand functions can be estimated, as a technical matter, for any product. No one would regard the statement 'the demand for socks (or potatoes or foreign holidays) is a stable function of a small number of variables' as politically contentious.

The two core principles in Lombard Street Research's work have a logically necessary implication. This is that when the supply of money changes, so also does the equilibrium level of nominal national income. Further, when the rate of growth of the money supply increases, so also does the equilibrium rate of growth of nominal national income. Another point follows quickly. It is common sense that nations cannot make themselves rich by the mere printing of money. In the long run real output must depend primarily on real considerations, such as the number of workingage people and their degree of skill. Hence, if the money supply is rising at a faster rate than the trend rate of output growth, an increase in the price level is likely, while an acceleration in money supply growth is likely to lead to a higher rate of inflation.

It has always seemed to me that these ideas ought to be accepted by anyone interested in economics. However, for all of the past 50 years they have been controversial to a greater or lesser degree. In the 1960s and 1970s the preferred style of policy-making in the UK relied on two alternative and quite different sets of ideas, corporatism and Keynesianism. ${ }^{3}$ The debates 
between monetarism, corporatism and Keynesianism are covered elsewhere in this volume and need not detain us here. At any rate, there is not much doubt that the late 1970s saw a radical reorientation of British economic policy. In particular, after the 1979 general election the Thatcher government rejected incomes policy as a method of controlling inflation and fiscal fine-tuning as an instrument of demand management.

So in the early 1980s it seemed that the monetary theory of the determination of national income and inflation had been adopted by the government, and that in policy-making circles it had become an accepted orthodoxy. Since money targets were expressed in terms of broad money, a logical deduction was that the officially favoured theory related to a broadly defined aggregate. This impression was misleading. In fact, it seems that none of the key players accorded broad money a prominent position in their view on national income determination, in so far as they had thought through the matter at all. ${ }^{4}$ The next few years were to see considerable difficulties in the agenda of monetary control, and the emergence of a far more eclectic, pragmatic and intellectually confused approach by policymakers. It should be emphasized that the new pragmatism did not include a return to incomes policies and fiscal fine-tuning, and that the UK therefore genuinely did have a 'monetarist counter-revolution'. Corporatism and Keynesianism were renounced by policy-makers in 1979 and 1980, and have never come back. Nevertheless, the emphasis on money supply targets as the centrepiece of policy was heavily diluted. As an economist in the City in the early 1980s, I commented every week on monetary developments and spent much of my time writing newspaper articles in defence of the money supply targets which had been introduced in the late 1970s.

Every quarter I prepared a research document, called Financial Analysis, which considered the financial position and monetary behaviour of the economy's main sectors. Apart from the banks and the public sector, these were the personal (or household) sector, the corporate sector (that is, companies as such, or 'industrial and commercial companies') and the financial sector (that is, 'non-bank financial institutions'). An abundance of data was available for analysis, because - following the recommendations of the Radcliffe Report ${ }^{5}$ of 1959 - a vast amount of information about the banking and financial systems has been compiled in the UK since 1963. It was my work for Financial Analysis that led me to organize my ideas about the so-called 'transmission mechanism' of monetary policy.

One point had seemed obvious to me from the early 1970s, although (as I gradually realized) it was far from obvious to most other economists. This point was that - if we want to understand the relationship between the quantity of money and the spending behaviour of those agents that matter to the business cycle - only a broadly defined, all-inclusive money supply 
measure is of interest. The so-called 'narrow money' measures have some information value, but narrow money measures have little or no causal role in the economy. The reason that narrow money has no causal role in the economy is quite simple, but it may help to elucidate the matter in a few paragraphs.

One of the most compelling theoretical constructs in economics is the notion of a 'general equilibrium'. Simplifying greatly, this is a situation in which the demand and supply functions for all products intersect at their equilibrium points, setting prices and quantities in the economy. As noted in the opening paragraphs to this essay, it is an essential aspect of a general equilibrium that the demand for money should equal the money supply. If the demand for money differs from the money supply, general equilibrium does not prevail. Agents try to eliminate the excess, or shortage, of money by spending above, or beneath, income or by asset re-dispositions. My view - much influenced by the boom-bust cycle of the 1970s, but also by wider reading of economic history - was (and remains) that most cyclical instabilities are the result of such 'monetary disequilibrium'. In other words, fluctuations in asset prices and expenditure are best interpreted as due to mismatches between the demand for money and the money supply, while these mismatches are due to big swings in money supply growth. Such swings arise, typically, from mistakes in interest-rate setting by the central bank, although they can have many other causes. These other causes can include an excessive budget deficit with consequent 'money printing', an inappropriate exchange rate and heavy foreign exchange intervention, and major financial deregulation and associated rapid credit expansion. Plainly, in this story excesses or deficiencies of money balances cause the adjustment of spending plans and asset portfolios, and the two pivotal parts of the process are the decisions taken by agents in their balancing of money against goods, and of money against assets.

In this context the trouble with any measure of narrow money is that it is only a sub-set of money as a whole. For example, in the UK consider the narrow money measure, M0, data for which were published between 1984 and 2006. It consisted mostly of notes and coin, and included no bank deposits. It was less than 5 per cent of the M4 aggregate, which was predominantly bank deposits and included virtually all conceivable money balances. If agents had excess or deficient M0, they could adjust their holding of M0 by transfers of funds between M0 and a non-M0 money balance inside M4. For example, they could transfer cash into or out of bank deposits. Such 'money transfers' restored the equivalence of the demand for M0 with its supply, but they did not affect spending on goods or asset portfolios. Monetary disequilibrium in M0 was therefore irrelevant to the business cycle. (It should also be mentioned that - in both the USA 
and the UK - the value of transactions in cash is less than 1 per cent of the value of all transactions. The notion that $\mathrm{M} 0$ could affect the major investment and portfolio decisions of large companies and financial institutions was particularly silly, since many of them held no cash whatsoever. Their money balances were entirely in the form of bank deposits. $)^{6}$

So an analysis of the relationship between money and the economy must be an analysis of the relationship between an all-inclusive money measure on the one hand, and the spending decisions and asset dispositions of the economy's main sectors on the other. I was amazed that in the early 1980s official policy de-emphasized broad money and paid an increasing amount of attention to M0. This shift of emphasis was partly due to some genuine, although much exaggerated difficulties in the relationship between broad money and expenditure in those years, but also important were criticisms of broad money made by some monetarist economists, notably Sir Alan Walters and Patrick Minford. I disagreed with Walters and Minford (as I still do), and made my disagreement known in various places. Despite the background, I persevered with my work on the UK's flow-of-funds data and sectoral monetary information, and began to notice certain regularities. By the mid-1980s the data series were typically over 20 years long and the number of observations in the key relationships implied acceptable levels of statistical significance. I noticed, in particular, three regularities.

Regularity I. The personal sector's demand-for-money function was more stable than that of the other private sectors' demand-for-money functions (that is, the demand for money function of the corporate and financial sectors, either individually or combined).

Regularity II. A key measure of the corporate sector's balance sheet strength was the ratio of companies' money balances to their bank borrowings, which I called 'the corporate liquidity ratio'. This liquidity ratio seemed to be relevant to their investment spending and to private domestic demand as a whole.

Regularity III. A key measure of financial institutions' attitude towards their money holdings was the ratio of their monetary assets, or liquid/'short-term' assets, to their total assets. Over long periods this ratio gravitated back to a value of about 4 per cent for the most important UK institutions (that is, the life offices and pension funds [LAPF]). I called this ratio 'the institutional liquidity ratio'.

It needs to be emphasized that none of these regularities had been much disturbed by the turbulence and financial deregulation of the early 1980s. An undoubted implication was that the rate of growth of the money supply, broadly defined, was critical to the economy's behaviour. 
In both the Heath-Barber boom of the early 1970s and a milder cyclical episode in the late 1970s (the Healey 'boomlet' of 1978 and 1979) I had noticed a pattern in the growth rates of the different sectors' money balances. This was that an upturn in the growth rate of the money supply was accompanied by only a small change in the growth rate of the personal sector's money, because of Regularity I. The upturn in money growth was therefore associated with much more pronounced increases in the growth rate of corporate and financial sector money than in the growth rate of aggregate money. Regularity II implied that the consequent sharp rise in the corporate liquidity ratio would lead to more investment spending and buoyant domestic demand, as well as to higher asset prices, in so far as companies tried to eliminate excess money by takeover activity and other asset purchases. Meanwhile Regularity III implied unusually large asset price increases. In both the Heath-Barber boom and the Healey boomlet asset price strength became general as companies and people - mostly rich people - bought and sold assets, to bring the valuations of the different assets, and of their monetary and non-monetary assets, into the right relationship with each other. The asset price strength infiltrated the markets for goods and services, and was followed by higher inflation at the retail level.

\section{II}

I was therefore astonished when in October $1985 \mathrm{Mr}$ Nigel (later Lord) Lawson, the Chancellor of the Exchequer, suspended (as a prelude to scrapping) broad money targets. The true explanation for this decision was that Lawson had come to regret his commitment to money supply targetry at the very start of the Thatcher government and instead preferred to base monetary policy on the exchange rate, particularly the exchange rate between the pound and the Deutschmark. In the year from October 1985 the annual growth rate of broad money accelerated sharply, by about 5 to 6 per cent on the M3 money measure, which included only bank deposits, and by about 2 or 3 per cent on the M4 measure, which included both bank and building society deposits. The acceleration continued into 1987, when the growth rate of M3 exceeded 20 per cent for the first time since the early 1970s.

Given the work that I had been doing over the previous 15 years, it was obvious to me that the money supply acceleration would lead to a boom and a significant increase in inflation. Moreover, I doubted that a later bust could be avoided if the UK were to restore an internationally respectable inflation rate. From early 1986 I warned about the risks in a sequence of articles in The Times, but my warnings were dismissed as lightweight journalism by key policy-makers in the Treasury and the Bank of England. 
Their refusal to take the warnings seriously prompted me to ask Peter Warburton - whose econometric expertise had previously been deployed on the highly regarded London Business School model - to join me at Messel/Shearson Lehman. The forecasts we prepared together between late 1986 and mid-1988 were detailed and rigorous, with forward projections of the money holdings of the personal, corporate and financial sectors, and related these agents' asset and expenditure decisions to their money balances. The forecasts were largely correct. The boom of 1987 and 1988 was followed by rising inflation and interest rates in 1989 and 1990, and by a bust between 1990 and 1992 .

However, in mid-1988 the outcome of the Lawson boom still lay in the future. After Messel had been bought by Shearson Lehman, my research department became accountable to executives in New York with little interest in British public policy issues, except in so far as they affected 'the bottom line'. My American employers gave me the opportunity to leave, which I was happy to take. In late 1988 I approached Mr Brian (later Sir Brian) Williamson, then a director of Gerrard \& National, to see whether his company would like to set up a joint venture with me. The joint venture would be a monetary research company, intended to produce forecasts of the British economy and sell them and other research work, mostly - but not exclusively - to large financial institutions. Mr Williamson persuaded the Gerrard \& National board to go along with the proposal. With a capital of $£ 100$ and a loan facility of $£ 50000$, Lombard Street Research began trading in July 1989. I was fortunate in my years at Lombard Street Research to enjoy the support and friendship of many excellent colleagues, who worked with me on UK monetary research and macroeconomic forecasting. As a result, the analytical approach I started at Messel was maintained. The first issue of Lombard Street Research's Quarterly UK Economic Forecast appeared in December 1989, with the opening sentence: 'Mr Lawson has bungled the electoral business cycle.' Page 9 contained an analysis of 'the sectoral breakdown of monetary growth', on much the same lines as the work done at Messel earlier. Later pages reviewed the money holdings and balance-sheet patterns of the personal, financial and corporate sectors, and related these to expenditure decisions. The format of the Quarterly UK Economic Forecast in 2004 was almost exactly as it had been in 1989. Our monthly Portfolio Strategy publication also had pages on financial institutions' and companies' liquidity positions, with the purpose of making assessments of likely future movements in asset prices and demand.

Did the linkages between money and the economy in the roughly 25 years of data to 1989 survive into the 15 years to 2004? In particular, did the three regularities continue to apply? In 1993 Simon Ward and I wrote a 
short econometric research note on the personal sector's demand for money. With a relatively simple specification in which income and the attractiveness of money relative to other assets were the key arguments, it was possible to show that the personal sector's demand for money had been stable, according to the usual statistical significance tests, for 30 years from 1963. Since the personal sector's money balances represented over half of all money, this was a very significant finding. The same equation - with minor amendments - worked fine in the second half of the 1990s, although it did begin to under-predict actual holdings in the opening years of the twenty-first century. Other researchers have also carried out econometric testing on the personal sector's money demand and reached similar results. ${ }^{7}$ Regularity I seems to have become more widely recognised.

What about Regularity II? I had noticed in the late 1970s and 1980s that fluctuations in the corporate liquidity ratio were loosely correlated with fluctuations in gross domestic product, while the ratio itself seemed to average a value slightly above a half. Admittedly, the ratio had been much higher than a half in the early 1960s. But, as the banking system was liberalized and became more competitive in the late 1960s and 1970s, companies seem to have decided that they could manage with lower liquidity. An important watershed was the Competition and Credit Control reforms of September 1971, which were intended to mark the end of quantitative controls on bank lending. In the 25 years from the start of data to the fourth quarter (Q4) of 1988 - that is, in the 25 years before the founding of Lombard Street Research - the average value of the corporate liquidity ratio was 59.4 per cent. Between Q3 1971 and Q4 1988 the average value of the ratio was a shade lower, at 56.6 per cent. The stability of the average value over such long periods led me to expect that the ratio would take much the same value in future. So what did happen in the 15 years to the end of 2003? The answer is that in this period the average value of the liquidity ratio was 57.4 per cent! In other words, UK companies have been operating with much the same notion of a sensible long-run average, or 'equilibrium', ratio of bank deposits to bank borrowings for over 30 years. The tendency of the ratio to revert to the same average value is all the more remarkable, given that in the just over 32 years from Q3 1971 to Q4 2003 their M4 holdings climbed from $£ 4.0$ billion to $£ 170.7$ billion (or by 42.2 times) and their M4 borrowings increased from $£ 6.9$ billion to $£ 270.0$ billion (or by 39.3 times).

To say that the ratio has had a tendency to revert to the same equilibrium value does not mean that it has stayed close to the equilibrium value all the time. As Figure 15.1 shows, there were large deviations from the average on the upside in 1972 and in the late 1980s, and on the downside in 1974, 1980 and 1990-91. The two upside deviations were periods of boom, whereas the 


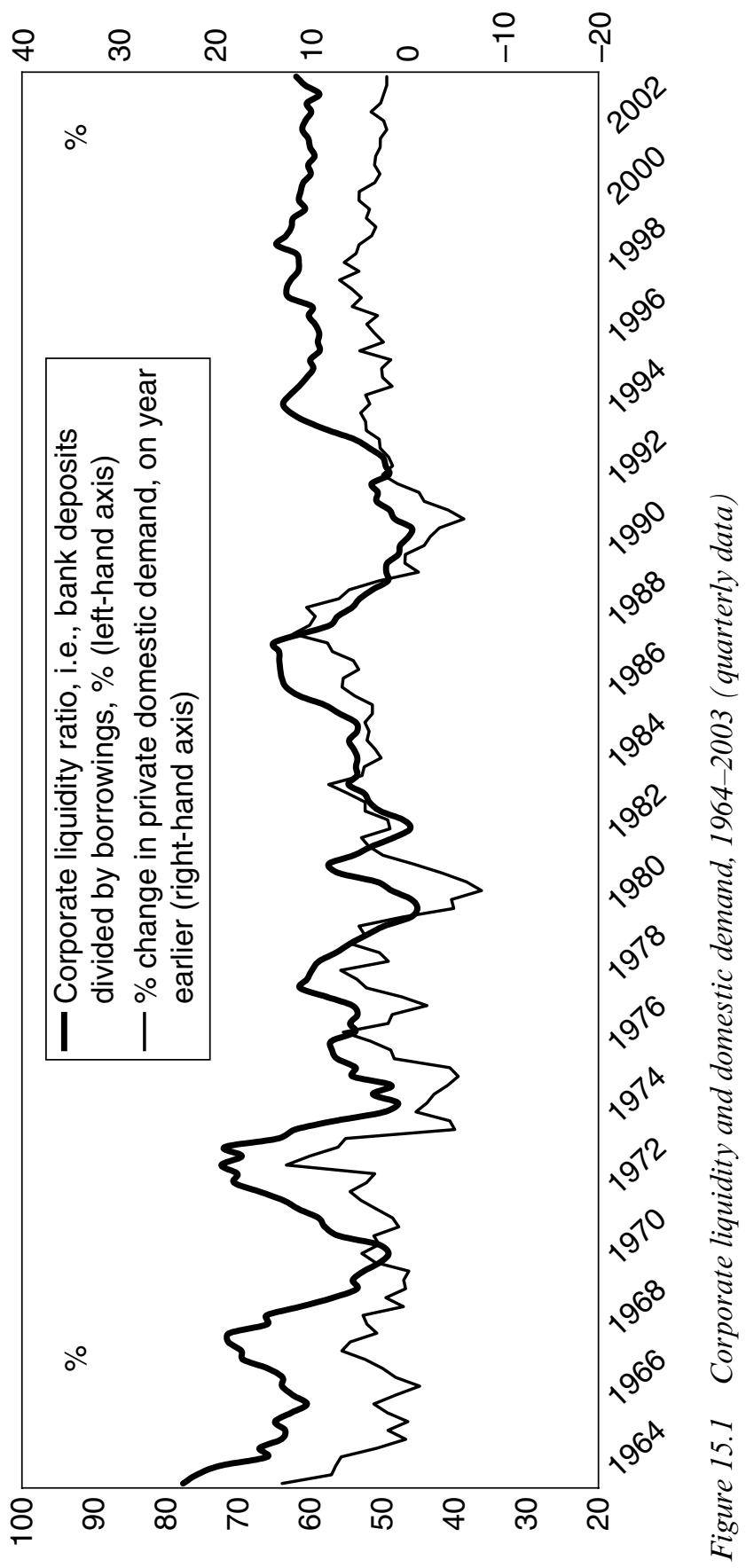


three downside deviations saw pronounced demand weakness. The rationale for the relationship is simple. When companies have strong liquidity they are inclined to spend more on capital equipment, recruitment and stock-building, but when liquidity is under pressure they cut back. (The appendix provides some econometric results on the relationship between the corporate liquidity ratio and private sector domestic demand.)

And what about Regularity III? In preparing this essay I checked the values of the institutional liquidity ratio over the 31 years to the end of 2003, that is, roughly speaking, the period in which expectations of neverending inflation had become established and made equities the core asset for most UK savings institutions. In the 16 years to end-1988 the institutional liquidity ratio averaged 4.33 per cent. The ratio saw sharp swings, from a value of over 9 per cent at the end of 1974 to under 3 per cent at the end of 1986. It is interesting that high values generally coincided with stock market weaknesses and low values with stock market strength. Over the 16 years life offices' and pension funds' short-term assets - mostly bank deposits - rose by a multiple of 13.5 times, from $£ 756$ million to $£ 20978$ million, while their total assets rose by a multiple of 14.5 times, from $£ 30224$ million to $£ 465820$ million. By contrast, the institutional liquidity ratio changed only slightly, falling by 7 per cent.

When I founded Lombard Street Research I expected that the ratio would vary significantly from year to year, as it had done in the past, but that its long-run average value would be much the same as it had been between 1972 and 1988. By checking the figures I was able to test this hypothesis. It turned out that the ratio in the 15 years to end-2003 averaged 4.37 per cent, astonishingly close to the average of 4.33 per cent in the 16 years to 1988 ! (See Figure 14.1 on p. 288.) Of course, this result is a fluke. It must be a fluke both because the ratio is volatile from year to year, and because the portfolio preferences of life offices and pension funds are different within the LAPF total. Nevertheless, the similarity of the institutional liquidity ratio in the periods $1972-88$ and 1989-2003 is striking, and implies that over a 30-year period senior executives in the UK's long-term savings institutions had a fairly stable notion of the appropriate ratio of monetary, or 'short-term', assets to their total assets. In the 31 years to the end of 2003 the LAPFs' short-term assets rose by 83.6 times and their total assets by 54.8 times, while the liquidity ratio changed by 52 per cent.

\section{III}

The conclusion has to be that the three regularities I noticed from the monetary data in the 25 years to 1988 survived to 2004. These regularities 
related to the monetary behaviour of the entire UK non-bank private sector. My view on these issues remains the same as when I founded Lombard Street Research. I continue to believe that the behaviour of the quantity of money, broadly defined, to include all bank deposits, is fundamental to the cyclical changes in asset prices and investment expenditure observed in the UK economy, and in other economies, and that these changes are in turn critical to demand, employment and inflation. I like to think that my work as a business economist has not only helped my clients, but also improved policy-makers' understanding of how the economy works.

\section{NOTES}

1. For an example of scepticism about the monetarist approach to the transmission mechanism, see the criticisms of Friedman made by Goodhart on pp. 190-91 of the 1st edition of his Money, Information and Uncertainty (London: Macmillan, 1975). But in the 2nd edition of Money, Information and Uncertainty (London: Macmillan, 1989) Goodhart was more sympathetic to the monetarist story, particularly when money was seen as a 'buffer-stock' to even out expenditure. (See pp. 281-5 of the 2 nd edition.)

2. Friedman claimed that the University of Chicago had an 'oral tradition' of monetary economics, which explained the distinctiveness of its monetary thought in the 1950 s and 1960s. The content of economics course at Chicago in those decades was undoubtedly very different from that in Cambridge, England, or Cambridge, Massachusetts.

3. As this is an autobiographical piece, I thought readers might be interested to know that one of my earliest papers - a critique of the then Conservative government's CounterInflation Programme - was published in The Bankers' Magazine in 1973. I had written it while at Nuffield College, Oxford, as a postgraduate student. Nigel Lawson was on the same staircase as a Journalist Fellow. He was working (with Jock Bruce-Gardyne) on a book on past blunders in British policy-making, published in 1976 as The Power Game. He very kindly took a few hours to read my paper and commented on it favourably.

4. From 1983 - when Nigel Lawson became Chancellor of the Exchequer - the four key individuals close to Treasury policy-making were Lawson himself, Sir Terence (later Lord) Burns, Sir Peter Middleton and Sir Alan Walters. (Burns was Chief Economic Adviser and Middleton Permanent Secretary to the Treasury, and - when he was not away Walters was Economic Adviser to the Prime Minister, Mrs Thatcher.) Lawson's views on broad money take up barely a sentence or two of his The View from No. 11 ([London and New York: Bantam Press, 1992] see pp. 78-9) and he was responsible for the introduction of the target for M0 (p. 453); Burns had written on 'international monetarism' and the role of differential monetary growth rates (in different countries) in determining the exchange rate before becoming Chief Economic Adviser in 1980, but he has made no substantial statement on money aggregates and the monetary transmission mechanism since then; Middleton never gave any written justification, in his own name, for whatever views he held in the 1980s on the money aggregates, but he poked fun at monetarists in his 1988 Jubilee Lecture to the National Institute of Economic and Social Research, and that probably represents his true position; Walters shilly-shallied in the course of his career between broad and narrow money, but in the 1980s was committed to narrow money, which he praised on pp. 116-20 of his Britain's Economic Renaissance (New York and Oxford: Oxford University Press, 1986). Of this group Walters was plainly the most interested in monetary economics and the transmission mechanism. For a critique of the views on the money aggregates expressed in Britain's Economic Renaissance, see T. Congdon, Money 
and Asset Prices in Boom and Bust (London: Institute of Economic Affairs, 2005), pp. 83-5. For a rather cynical survey of the beliefs of the various players, see G. Pepper and M. Oliver, Monetarism under Thatcher: Lessons for the Future (Cheltenham, UK and Northampton, MA, USA: Edward Elgar, 2001).

5. Report of the Committee on the Working of the Monetary System (Cmnd. 827) (London: HMSO, 1959).

6. This point is made, in criticism of Minford's views on M0, on pp. 78-83 of T. Congdon, Money and Asset Prices in Boom and Bust (London: Institute of Economic Affairs, 2005). See also Essay 14, particularly pp. 304-7.

7. See note 23 to Essay 12. 


\section{APPENDIX: THE RELATIONSHIP BETWEEN CORPORATE LIQUIDITY AND PRIVATE SECTOR DOMESTIC DEMAND IN THE UK, 1964-2003}

The argument in the text was that - because of the effect of their balancesheet strength on companies' investment spending (among other things) the change in private sector domestic demand could be interpreted as heavily influenced by the corporate liquidity ratio (that is, the ratio of industrial and commercial companies' bank deposits to their bank borrowings). Figure 15.1 showed the two series over the 1964-2003 period. (The change in private sector domestic demand was the annual change, that is, the percentage change in the last four quarters, in real terms.)

The following equation relates to the two series over the entire Q1 1964-Q4 2003 period:

Change in real private sector domestic demand (per cent p.a.) $=-13.63$

+ 0.28 Corporate liquidity ratio, $\%$

$\mathrm{R}^{2}=0.28$

t statistic on regression coefficient 7.85

The equation for the 25 years from Q1 1964 to Q4 1988 (i.e., the 25 years before the founding of Lombard Street Research) was as follows:

Change in real private sector domestic demand (per cent p.a.) $=-\mathbf{1 2 . 5 6}$

+ 0.27 Corporate liquidity ratio, $\%$

$\mathrm{R}^{2}=0.23$

t statistic on regression coefficient 5.43

The equation for the 15 years from Q1 1989 to Q4 2003 (that is, the 15 years from the founding of Lombard Street Research) was as follows:

Change in real private sector domestic demand (per cent p.a.) $=-16.56$

+0.33 Corporate liquidity ratio, $\%$

$\mathrm{R}^{2}=0.48$

t statistic on regression coefficient 7.37

This exercise shows that the relationship between corporate liquidity and the change in private domestic demand - which I had noticed before setting up Lombard Street Research in 1989 - was more well defined in the subsequent 15 years than in the previous 25 years. The corporate liquidity ratio which is plainly a monetary variable (as it includes bank deposits) - was 
useful as a forecasting tool. The claim that monetary variables are unhelpful in forecasting (because of 'instabilities', 'the breakdown of relationships', and so on) was wrong, at least in my experience with these particular variables. 
Tim Congdon - 9781847206923 Downloaded from PubFactory at 04/26/2023 12:12:52PM via free access 